\title{
The Aerating System of Vicia Faba.
}

BY

\section{HUNTER, M.Sc.}

\section{With six Figures in the Text.}

THE exchange of gases which is essential for the respiratory activity of each individual living cell of a green plant is carried on by means of an intricate system of intercellular spaces, which is continuous throughout the plant, and ultimately comes into connexion with the air external to the plant by means of stomata and lenticels. De Bary ${ }^{1}$ has carefully described the different forms of intercellular spaces and the manner in which they arise, but the physiological significance of the intercellular spaces of an ordinary green plant cannot be said to have received sufficient emphasis. The aerating system is quite as important to the plant as the waterconducting system or the food-conducting system. In order to obtain some idea of the complete aerating system of a plant, it was determined to work out in detail that of a variety of the Broad Bean-Vicia Faba-which is known as the Horse Bean. The plants examined were grown in a mixture of fine soil, sand, and leaf-mould. This potting-soil allowed ready access of air to the roots, and was also rich in food material. The plants were not subjected to any abnormal temperature conditions, as they were grown either in a cold frame or else completely in the open air. The results obtained for each group of plants were similar, and proved that the protection afforded by the cold frame did not affect the structure of the different organs.

The presence of air in intercellular spaces was demonstrated by mounting hand-cut sections either in pure glycerine or in glycerine jelly. Any air which was present in the sections was rendered visible under the microscope, owing to the great difference between the refraction of the rays of light by the gas and by the surrounding medium; and also owing to the reflection of the light rays on striking the under surface of the gas. The air present in the small intercellular spaces of the sections showed up as dark masses, quite distinct from the surrounding cells. This method was particularly successful in the case of longitudinal sections.

1 De Bary : Comparative Anatomy of Phanerogams and Ferns, p. 201 et seq.

[Annals of Botany, Vo1, XXIX. No. CXVI. October, 1915? 
Seeds of Vicia Faba were soaked in water for twelve hours and then sectioned. The structure of the testa is similar to that of Phaseolus as described by Haberlandt, ${ }^{1}$ and to that of Pisum sativum as described by Detmer. ${ }^{2}$ The general arrangement of the tissues of the seed-coat is as follows :

(a) An epidermis composed of thick-walled cells of palisade pattern. This layer is compact, and intercellular spaces are completely absent.

(b) A layer of pillar-shaped cells alternating with large intercellular spaces. This form of cells is probably determined, as in water plants, by a demand for increased air space, without interfering with the movement of water from without the seed to those portions which are in need of it.

(c) Tissue consisting of parenchymatous cells having their greatest axis in a direction parallel to the surface of the seed.

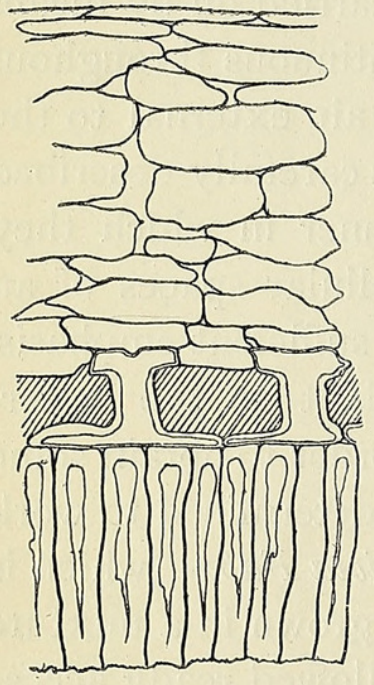

FIG. I. Testa of Vicia Faba, transverse section showing the three types of tissue. The large lacunae of the middle layer are diagonally shaded. $\times$ I 80 . Intercellular spaces are present in this tissue, but they are of quite a different nature from those of the middle layer, and are quite typical of the intercellular spaces which usually occur in parenchymatous tissue. This layer of cells forms nearly one-half of the soaked testa, but in the dry seed the cells are in a collapsed condition, and only regain their turgid state on the absorption of water.

Text-fig. I shows the general arrangement of these different layers of cells which go to compose the testa.

Thin hand-sections of the cotyledon were washed gently in water in order to remove the masses of reserve material which would have prevented a careful examination of the tissues. The sections were then mounted in glycerine jelly. The cotyledon was found to consist of three distinct types of tissues :-

(a) An epidermis consisting of small, cubical, compact cells. Stomata were completely absent, and the layer possessed no intercellular spaces.

(b) Vascular tissue devoid of intercellular spaces.

(c) Parenchymatous storage tissue.

The storage tissue is permeated by an intricate aerating system. This does not consist merely of the triangular or rectangular intercellular spaces such as are figured by Sachs, ${ }^{3}$ in the case of cells from the cotyledon of Pisum sativum. The aerating system of the parenchymatous storage cells of Vicia Faba forms a conspicuous feature of the sections, and consists

1 Haberlandt: Sitzungsb. der K. Akad. Wien, Naturwissenschaften, Bd. 75 (I877), p. 33.

2 Detmer and Moore: Practical Plant Physiology, p. 192.

3 Sachs: Lectures on the Physiology of Plants, p. $5^{2}$. 
of continuous intercellular spaces which are capable of bringing about a most active exchange of gases. The gaseous exchange between the living contents of the cells and the air in the intercellular spaces can only take place through the cellulose cell-walls when they are in a moist condition. ${ }^{1}$ It has been observed that bands of some material less refringent than air occur in these canal-like intercellular spaces. It seems highly probable that these are masses of water, which assist in the active exchange of gases by keeping the cell-walls in the necessary moist condition. Similar masses have been noted in the intercellular spaces of the cortex in longitudinal sections of the root of Lupinus.

The arrangement of the large air-cavities which are present in the stem of Vicia Faba is very instructive.
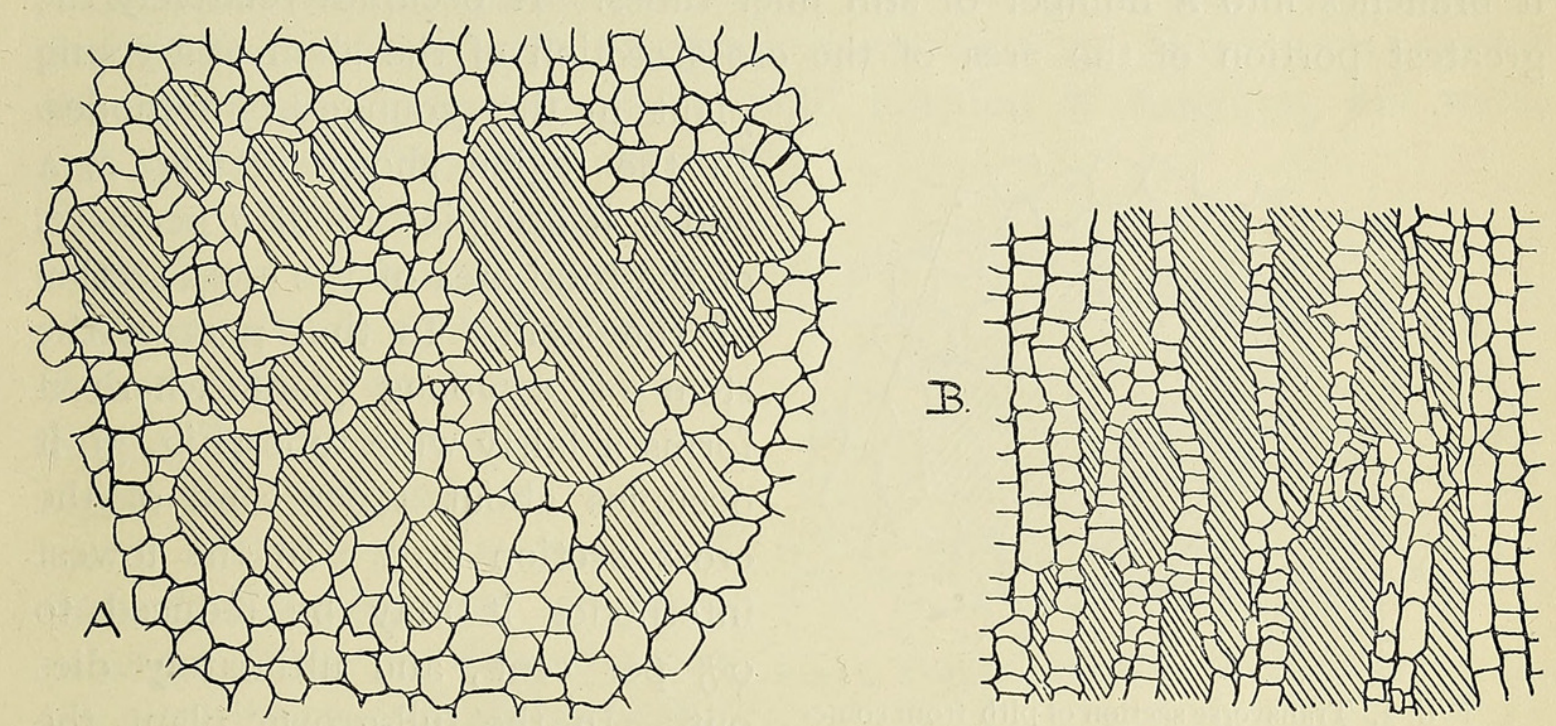

FIG. 2, A and B. Transverse and longitudinal sections of pith of young internodes, showing air-cavities (diagonally shaded) separated by sheets of active cells. $\times$ Ioo.

In the youngest internodes the centre of the pith is traversed by strands of active cells separated by well-marked air-cavities, as is shown in Fig. 2, $\mathrm{A}$ and B. The structure of the pith in this region is comparable with the arrangement of the ground-tissue in the stems of many aquatic plants. These cavities in the youngest internodes of Vicia Faba gradually become smaller as the growing point is approached, until they are reduced to mere chinks in the meristematic cells of the embryonic tissues. It is evident that the cavities are of schizogenic origin, as they result from the unequal development of the plerome in a radial direction. Lower down the stem these strands of active cells disappear, and one large central cavity replaces the much divided cavity of the younger internodes-see Fig. 3. This cavity is produced by the disorganization of the separating strands of cells. The remains of the cell-walls of these strands are to be found along the edges of the cavity. This cavity is therefore produced in

1 Livingston: The Rôle of Osmotic Pressure and Diffusion in Plants, p. i I 6. 
a different manner from the smaller cavities above it, and is clearly of lysigenic origin. Here, therefore, is an example of a number of schizogenic intercellular spaces enlarging into air-cavities which are converted into one lysigenic cavity. The transformation might be described in the terms employed by Frank, ${ }^{1}$ as of protogenetic origin, because the cavities are really produced in the earliest differentiation of the tissues, and of subsequent hysterogenetic development, since the final form appears only in the older mature stem. In the mature plant this central cavity extends for the greater part of the stem, but in the lower internodes it decreases in size, and ultimately disappears completely. This central air-cavity may be described as a very fine tube, gradually tapering in the oldest internodes and finally disappearing completely, whilst in the region of the stem apex it branches into a number of still finer tubes. It occupies relatively the greatest portion of the area of the cross section of the stem of a young

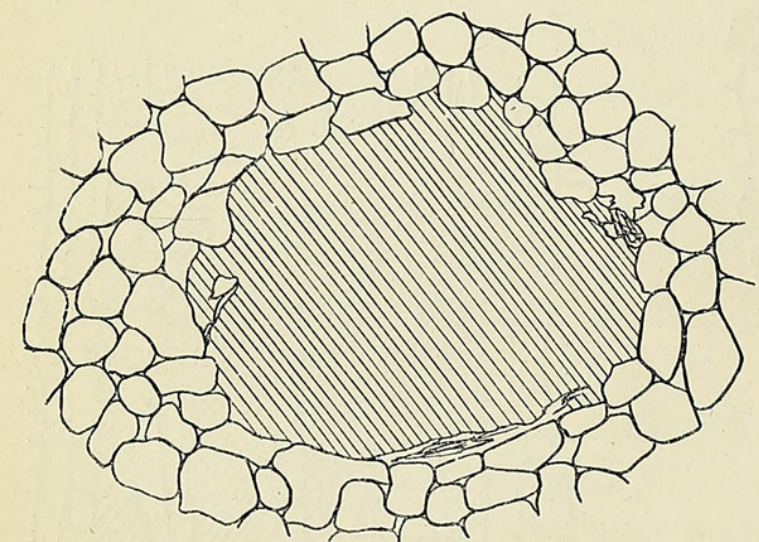

FIG. 3. Transverse section of pith from somewhat older internode than that of Fig. 2. Central cavity developed. $\times 100$. plant in the youngest internodes. In the region shown in Fig. 2, A and $\mathrm{B}$, it occupies about 7 per cent. of the total area of the cross section of the stem. In that part of the stem of a young plant where it forms a fairly wide tube (Fig. 3), it occupies about 4 per cent. of the cross section area. In the lowest internodes it may be reduced to 0.5 per cent., and ultimately dies out. In the full-grown plant the central cavity may occupy 50 per cent. of the cross section of the stem. The cells at, and near to, the growing point naturally require a large supply of oxygen to assist in the processes necessary for their growth and division. A longitudinal section of the growing point shows that intercellular spaces occur amongst the very youngest cells, and are only absent amongst those cells which have just been formed. It seems quite reasonable to suggest that the large relative area occupied by the cavities in the young internodes is a device to secure a sufficient aerating system for this active region, and that the division of the cavity will assist in the even distribution of the oxygen for respiration, and the removal of the resulting carbon-dioxide.

In the lowest and oldest internodes no central cavity is present, but an interrupted ring of lysigenic cavities, occupying about 2 per cent. of the area of a transverse section, occurs (Fig. 4). It is rather difficult to understand what is the function of this arrangement of cavities. In the

\footnotetext{
1 Frank: Beitr. zur Pflanzenphysiologie, p. IoI.
} 
exchange of gases which is necessary for root-respiration, the gases must either travel long distances from the aerial breathing organs, or must enter and leave the root by diffusing through the outer walls of the limiting layer of cells. Whatever system is employed must provide for an efficient exchange of gases-the removal of carbon-dioxide, and the provision of oxygen. The following statement by Jost ${ }^{1}$ is of interest in this connexion: 'An investigation of the intercellular space system of all plants, whether aerial, subterranean, or submerged, teaches us that the accumulation of carbon-dioxide and deficiency in oxygen never reach a degree worth considering, and hence the means at the disposal of a plant are always sufficient for maintaining a gaseous exchange. Carbon-dioxide to the extent of 5 per cent., and oxygen as low as 8 per cent., are seldom met with in intercellular spaces, and Pfeffer and Celakowski have shown that in the interior of living cells oxygen is never wanting.' Livingston ${ }^{2}$ regards the root hair as having the twofold function of absorbing soil water, and acting as a breathing organ. Wacker $^{3}$ is of the opinion that land plants are unable to supply oxygen to their roots by way of their aerial breathing organs. Norris ${ }^{4}$ has shown that air passages can be produced in the cortex of roots of Zea mais, and that the development of these passages seems to depend upon the quantity of air available in the

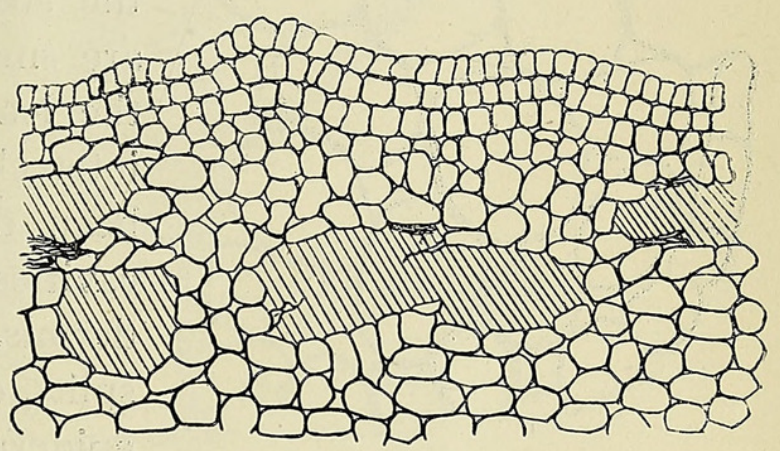
medium surrounding the root. Poor aeration resulted in the production of large air passages, but the roots of plants in media where there was a sufficient supply of air had normal intercellular spaces. Investigations by the present writer ${ }^{5}$ suggested that artificial soil aeration resulted in increased growth of plants. This has been confirmed by more recent work, and similar results have been obtained in water-culture experiments which have been carried out at the Rothamstead Experimental Station. ${ }^{6}$ From this evidence it would appear that the root does obtain some of the oxygen it requires by means of the root-hairs, and that, at any rate in some cases, this must be considerably augmented by a supply from the stem tissues to the living cells of the older portions of the root. To apply this to the

1 Jost : Plant Physiology, p. 195.

2 Livingston : ibid, p. I I6.

3 Wacker : Die Beeinflussung des Wachsthums der Wurzeln durch das umgebende Medium. Jahrb. wiss. Bot., 32, pp. 7I-II6.

4 Norris : Proceedings Bristol Naturalists' Society. Fourth Series, vol. iii, pp. I 34-5.

5 Hunter : Proc. Univ. Durham Phil. Soc., vol. iv, Part 4, p. 186.

6 Hall, Brenchley, Underwood : Phil. Trans. Royal Soc., B., vol. 209, p. 194. 
case of Vicia Faba: it will be seen that the cortical air-cavities of the stem would form an excellent means of supplying air to the parenchymatous cells in the cortex of the old root. These cells are a considerable distance from the nearest root-hairs, and the lysigenic cavities in the oldest internodes of the stem may be a device for bringing about a sufficient gaseous exchange in this region.

The intercellular spaces in the ground tissue of the stem are very varied in shape. In young ground tissue they are all triangular in transverse section, but in the mature ground tissue this is not the case. Owing to the fact that the cells vary a great deal in size, the original triangular intercellular spaces give place to more complicated shapes (Fig. 5). These result from the irregular development of the parenchymatous cells, and the subsequent fusing of two or more intercellular spaces. The intercellular space system of the ground tissue of the stem is brought into communi-

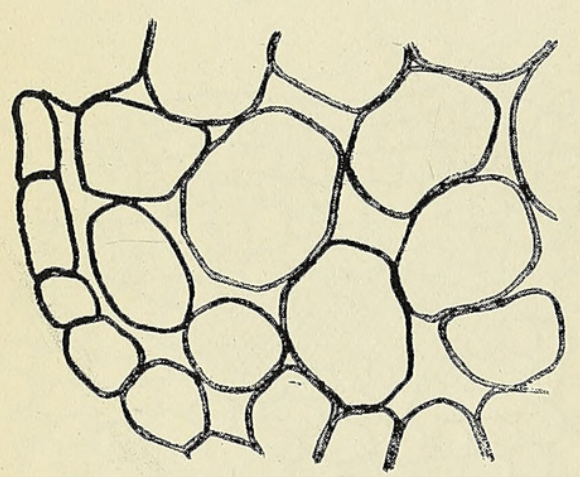

Fig. 5. Ground tissue showing various forms of intercellular spaces resulting from the fusion of two or more spaces. cation with the external air by means of the stem stomata. The stomatal cavities are small and quite distinct from those of the leaf. In addition to the cavities and intercellular spaces of the stem which have been described, there are present curious cavities one layer of cells below the epidermis. These take the form of long narrow splits, elongated in a plane parallel to the epidermis, and are similar to those which are present in the stem of Lamium.

The palisade cells of the leaf of Vicia Faba are not arranged regularly. Each palisade cell borders upon an intercellular space. These intercellular spaces are irregular in size-some are small and triangular in a vertical section, whilst others are considerably larger than the cells which they separate. The intercellular spaces of the spongy mesophyll are large and irregular. In a transverse section of the petiole, on the other hand, the intercellular spaces are small and triangular.

A longitudinal section of the root-tip shows that the intercellular spaces are just as important here as at the stem-apex (see Fig. 6, at the bottom). Intercellular spaces are not very marked in the root-cap, but they are present very extensively in the youngest tissues of the root. Probably the air which they contain is obtained from that portion of the root which bears the root hairs. In transverse section these intercellular spaces appear triangular in form. With reference to the older roots, it is worthy of notice that splits often take place in the cortex. How far these are the result of the boring operations of the lateral roots, and to what extent they are due to active growth, has not been determined, but either 
primarily or incidentally they take an important part in the respiratory activity of that portion of the root which is some distance from the roothair bearing region, and also from the aerial portions of the plant.

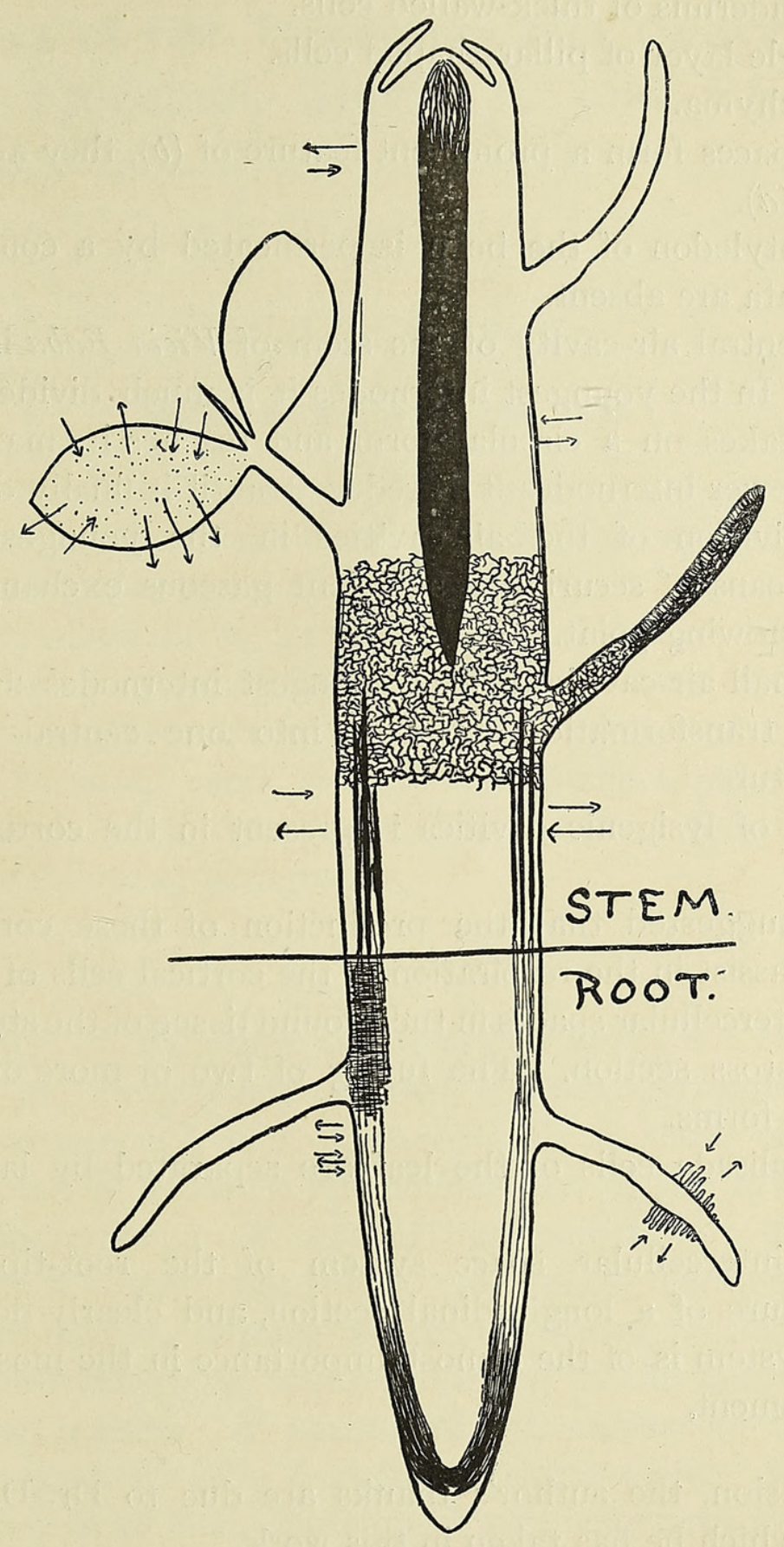

FIG. 6. Schematized longitudinal section of Vicia Faba illustrating the distribution of the aerating system in different regions of the plant.

A consideration of the evidence which has been brought together leads to the conclusion that the aerating system of Vicia Faba is elaborately adjusted, in order to ensure an efficient gaseous exchange for each living cell, no matter where its position may be in the plant tissues. 


\section{Summary.}

I. The testa of the bean is composed of three definite layers:

(a) An epidermis of thick-walled cells.

(b) A single layer of pillar-shaped cells.

(c) Parenchyma.

Intercellular spaces form a prominent feature of $(b)$, they are present in $(c)$, and absent in $(a)$.

2. The cotyledon of the bean is permeated by a continuous aerating system ; stomata are absent.

3. The central air-cavity of the stem of Vicia Faba is not uniform in cross section. In the youngest internodes it is much divided, in the central internodes it takes on a circular form and reaches its maximum development, and in lower internodes it is reduced until it finally disappears.

4. The division of the air-cavities in the youngest internodes is probably a means of securing a sufficient gaseous exchange in the active region of the growing point.

5. The small air-cavities of the youngest internodes are of schizogenic origin. The transformation of these into one central air-cavity is of a lysigenic nature.

6. A ring of lysigenic cavities is present in the cortex of the oldest internodes.

7. It is suggested that the production of these cortical air-cavities is a device to assist in the respiration of the cortical cells of the old root.

8. The intercellular spaces in the ground tissue of the stem are originally triangular in cross section. The fusing of two or more of these results in more complex forms. spaces.

9. The palisade cells of the leaf are separated by large intercellular

I0. The intercellular space system of the root-tip forms a very important feature of a longitudinal section, and clearly demonstrates that the aerating system is of the utmost importance in the most active regions of cell development.

In conclusion, the author's thanks are due to Dr. Darbishire for the kind interest which he has taken in this work.

The University, BRISTOL. 


\section{$2 \mathrm{BHL}$ Biodiversity Heritage Library}

Hunter, C. 1915. "The aerating system of Vicia faba." Annals of botany 29, 627-634. https://doi.org/10.1093/oxfordjournals.aob.a089571.

View This Item Online: https://www.biodiversitylibrary.org/item/243629

DOI: https://doi.org/10.1093/oxfordjournals.aob.a089571

Permalink: https://www.biodiversitylibrary.org/partpdf/320088

\section{Holding Institution}

Smithsonian Libraries

\section{Sponsored by}

Biodiversity Heritage Library

\section{Copyright \& Reuse}

Copyright Status: Not in copyright. The BHL knows of no copyright restrictions on this item.

This document was created from content at the Biodiversity Heritage Library, the world's largest open access digital library for biodiversity literature and archives. Visit BHL at https://www.biodiversitylibrary.org. 